\title{
Papuan Students' Behavior amid Yogyakarta Community Environment
}

\author{
Nurrizka, A. F ${ }^{1}$, Kartono D. $T^{2}$, Zuber, $A^{3}$ \\ ${ }^{1}$ Student of Master of Sociology of Faculty and Social and Political Science \\ of Sebelas Maret University \\ ${ }^{2.3}$ Department of Sociology of Faculty and Social and Political Science \\ of Sebelas Maret University \\ Ir Sutami Street No. 36 A, Surakarta, Indonesia \\ Corresponding email: annisafitrahn@ @student.uns.ac.id
}

\begin{abstract}
This research employed a descriptive qualitative method, in which data and material needed was obtained from interviews, observation, and based on $\mathrm{f}$ literature study on journals, documents, electronic media and mass media with descriptive analysis. This research aimsed It aims to analyze and to describe the behavior of Papuan students living in community environment in Yogyakarta. From the result of research on the students studied, it could be found that some of students studied had organizational behavior along with surrounding people by participating in some society activities, such as gotong royong (mutual cooperation), rapat $R T$ (neighborhood meeting), safeguarding environment, and etc. However, on the other hand in some areas of Yogyakarta, for example some people are not willing to accept their presence and giving them dwelling such as boarding house, so that it indicates discrimination againstPapuan students. It is due to dysfunctional behavior, they have thereby disrupting integration and socialization process in society. Papuan students consider that their behavior is commons, but is s unacceptable to society. They make noise by speaking loudly, drinking, and some act ions resulting in conflict with surrounding people. Meanwhile, they should create a relationship and structure with society in the environment where they live.
\end{abstract}

Keywords: Papua student; behavior; community

DOI: $10.20961 /$ ijpte.v\%vi\%i.26230

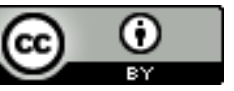

Except where otherwise noted, content on this site is licensed under a Creative Commons Attribution 4.0 International License. 


\section{INTRODUCTION}

Yogyakarta is known as a student city, in wich it has so with many universities, either both public or private. It is unsurprising that many students from outside come in throng go to study there. The is city's attraction lies not only in its education, metter but also ion its tourist attractions and low living costs. This is city as if It seems that never fading it will continue to prosper, as its population is increasing continuously because of the many students studying there, including those coming from Papua. It is reported that there are more than 0Papuan students studying there up to this year (bbc.com); the difference in of culture between Papuan students and the Yogyakarta people, of course, enables Papuan students to adjust them selves and to adapt to the Yogyakarta environment. Many ofPapua students who are able to well behave well and not deviate, and are able to interact and organize with the surrounding communities, and adapting well to in the its environment.

As suggested by a student informant named AR living in Papua Barat dormitory, "all of us living in this dormitory participate in organizations along with the surrounding people, and we sometimes attend rapat $R T$, gotong royong, and other $R T$ activities. It is because we have been accepted well and we can maintain our behaviour". These students attempt to make themselves acceptable to the surrounding people by means of participating in organizations along with society in order to strengthen their relationship between fellows with them. Thus, it can be seen that not all Papuan students have display dysfunctional behaviour, as many of them conduct themselves functionally in the city and maintain tolerance and cultural harmony as far as possible.

But viewed from however, Endah's (2016) study found that some people in Babar Sari village refuse to provide boarding house accommodation to Papuan students, due to the Yogya people's negative ethnic stereotyping against Papuan students them. This it makes Papuan students feel the discriminated againstion. Considering the results of previous studies, it can be seen that the community's declination hostility against Papuan students is due to Papuan students' their devianting behaviour, resulting in transgressions such as drinking and even generating conflict with community organizations in the Yogyakarta area.

Behaviorit self, according to Skinner (1938), is the result of any human experience and interaction with his the environment manifested in knowledge, attitude and action. There are some Various factors affecting behavior, including knowledge, emotional quotient, emotion, motivation, experience, environment, social economy and culture. and etc. In addition, as suggested by Angelika (2013), in her study, the image of Papuan students is bad enough negative in the community's eyes. Papuan students are related with to negative behaviours such as consuming liquor, causing disorder, violence and quarrel, being undisciplined, emotional and not obeying the traffic regulation. Furthermore, Angelika (2013) found that considering the stories of some Papuan students, most owners of boarding houses such as Pogung and Timoho refuse to lease their boarding room or house to Papuan students because they often make disturbance. During While drinking and quarrel, they often destroy boarding house. Sometimes, non-student foreigners or other Papuan students come to invade their boarding houses and 
threaten the citizen' security. The habit of assembling and consuming liquor or engaging in quarrels can no longer be tolerated, so that some members of community decide to refuse providing boarding house lodging to Papuan students. Negative perception, according to Sutarno (Herimanto, 2010), is a form of cultural disease. Cultural diseases include, among others, ethnocentrism, stereotype, prejudice, scapegoating, racism and discrimination. As suggested by Robert K Merton, student behaviour can be divided into functional behavior and dysfunctional behavior. In his functional structural theory, Merton proposed three postulates (Poloma, 2010). First, the functional unit of the community can be limited as "a condition in which all parts of the social system work together in adequate harmony or internal consistency without resulting in prolonged irresolvable or ungovernable conflict". This it means that the perfect functional unit of a community is "in contradiction with fact". It is just like some community habits are functional for a group (supporting a group's integration and cohesion) but dysfunctional for another (accelerating its destruction). Secondly, universal functionalism considers that "all of standard social and cultural forms have positive functions".As we know, Merton introduce both dysfunction and positive function concepts. sSome social behaviors are clearly dysfunctional.

Merton recommends cultural elements to be considered according to functional consequence balance criteria weighing positive and negative functions. Thirdly, what equips functionalism postulate is indispensability postulate.

Thus, it can be seen that not all Papuan students have dysfunctional behavior; some of them have functional behavior in Yogyakarta and maintain tolerance and harmony in culture as much as possible.

\section{METHOD}

This study employed a descriptive qualitative research method in which data or material needed was obtained from the result of interview observation and based on literature study on journals, document, electronic media and mass media with descriptive analysis. Nawawi (1991:63) defined descriptive research as a problem solving procedure, investigated by describing or depicting current condition of research subject or object (an individual, aninstitution, a society and etc.) based on actual fact, in order to draw conclusions as the result of analysis on research problems. This research was take place in Yogyakarta, with Papuan students being the target of research.. This study employed data source including field notes interview transcript recorded in both written note and recording and direct observation. In addition, secondary data source was also employed through literature study on journal, document, electronic media and mass media such as newspaper. Literature study, according to Nazir (1988), is technique of collecting data by studying books, literature, notes and reports relevant to the problems to be solved. This research was intended to Papuan students studying in Yogyakarta and took some previous studies as the data source. Data validation was carried out using source triangulation technique, the one employing more than one source to get more valid and to be analyzed well. . Techniques of analyzing data used were data collection, data reduction, data display, and conclusion drawing 
and verification stages, with the presence of sources like documents journals, and etc. The author got so much information as a material to be reprocessed later to conduct this research.

\section{RESULTS AND RESEARCH}

It departs from Robert K Merton's Structural Functionalism Theory emphasizing on objective consequences of individual behavior. Merton ( in Ritzer, 2006) in his theory suggests that some behaviors lead to integration and balance (manifest function), but there are also objective unintended and unknown consequences of individual behavior (latent function). Therefore, he assumes that some objective consequences of individual behavior are functional, and some others are dysfunctional. Dysfunction, according to Merton, is objective consequences of individual behavior that can be either functional or dysfunctional. The objective consequences of individual behavior can lead to integration and balance, while objective consquence of individual behavior that is dysfunctional will attenuate integration. Dysfunction will lead to tension and conflict in social system, thereby resulting in an alternative structure as a substitution to neutralize the tension. In addition, dysfunction will also result in anomie and social problem.

Merton (in Poloma, 2010) in his Functional Structural theory proposes three postulates. Firstly, the functional unit of community can be limited as "a condition in which all parts of the social system work together in adequate harmony or internal consistency without resulting in prolonged irresolvable or ungovernable conflict. It means that the perfect functional unit of a community is "in contradiction with fact". It is just like some community habits are functional for a group (supporting a group's integration and cohesion) but dysfunctional for another (accelerating its destruction). Secondly, it is universal functionalism". Thirdly, what equips functionalism postulate is indispensability postulate. Merton says that "in every civilization type and habit, idea, material object, and belief have some important functions, a number of tasks to do, and are the important elements inseparable from system activity as a whole.

Considering the theory above, in relation to Papuan students' behaviour in Yogyakarta , the author divided behavior into two parts:

\section{a. Functional Behavior}

Functional behavior is the form of cooperation in an adequate internal harmony level, without resulting in prolonged and irresolvable conflict. As afore mentioned, some Papuan students living in this dormitory attempted to be acceptable to surrounding society by means of participating in organizations along with surrounding people in order to strengthen the relationship between follows. . Thus, it can be seen that not all Papuan students have dysfunctional behavior, as many of them have functional behavior in Yogyakartaand they maintain tolerance and cultural harmony as maximally as possible in Yogyakarta.. They can penetrate into community and get closer to the society in their environment. They participate in gotong royong (mutual cooperation), and, even contribute to rapat $R T$ (neighborhood meeting) along with local people and participatein anyactivities held by the community. As afore mentioned, AR, an informant constituting Papuan 
student, said "all of us living in this dormitory participate in organizations along with surrounding people, and we sometimes attend Rapat RT, gotong royong, and other RT activities. It is because we have been accepted well and we can maintain our behaviour". Papuan students can develop tolerance and be reliable in contributing to safeguarding surrounding environment. In addition, Papuan students with their ability contribute to helping those affiliated with organization and encountering drought. "We think that violence against Papuan people and students is unjustifiable for the sake of humanity", said PPLP KP and WTT administrator. Papuan students have helped not only people in coastal area of Yogya South Beach but also those in Miliran Village, Umbulharjo, and around Papuan students' dormitory living closely to the students. "When the wells of Miliran villagers were dry because groundwater is sucked by hotels established surrounding, Papuan students help conduct advocacy. Papuan students a long with Miliran villagers made a protest against the hotel, even when many Yogya people instead did not care about such the issue", said one of Yogya citizens, Elanto Wilanto Wijoyono to CNNIndonesia.com, Monday (18/7/14). Thus, in this case, the students can adapt to surrounding environment and achieve their objective to penetrate into the community in Yogyakarta.

\section{b. Dysfunctional Behavior}

It is behavior generating tension or conflict in social system. In addition, dysfunction will result in anomie and social problem. Meanwhile according to Papuan students, their behavior is common, so that the image of Papuan students becomes negative in the community's eyes due to some Papuan students' bad behavior. This behavior results in restlessness and anger among the people surrounding, so that it culminates with the people's reluctance to provide boarding houses for Papuan students. This negative stigma creates discrimination against Papuan students, and ethnic stereotype within community,, negative perspective on certain ethnic . These deviating behaviors of Papuan students have been studied by Angelika (2013), finding that they drive haphazardly on the street and like to consume liquor. As a result, many people feel worry seeing Papuan students drinking on the street, and not reprimanding them bravely as they do not want to provoke reprimand commotion occurding when Papuan students cannot accept their reprimand, as during drunk their behavior becomes brutal violent. The difference of habit, rule, norm and culture between Papuan students and Yogyakarta environment is considered as the factor causing their different behavior, and it is possible difficult to follow the community's soft, gentle and decorous behavior. However, behind these characteristics, functional behavior of some Papuan students can neutralize the condition in some members of community.

\section{CONCLUSION}

From the explanation above, it can be concluded that some of Papuan students have organizational behavior within community in the attempt of establishing a good relation with surrounding people. In addition, an ethnic stereotype arises against Papuan, ethnic leading to discrimination encountered by Papuan students . 
Meanwhile, viewed from their behavior, not all Papuan students have bad behavior. Some of them come to Yogya to study actually and do not perform deviating action, but as they have been labeled negative by community members, it is difficult for Papuan students to unite with the community in the term of mutual cooperation and self-adaptation to different culture. It is this so different culture that results in different behavior among Papuan students, in which they have, harsh attitude and speech that is in contradiction with Yogyakarta people, who are softer and gentler. As newcomers, Papuan students should be able to follow culture, norm and rule prevailing in Yogyakarta community, thereby not resulting in negative stigma among the community, and the community is expected to accept any newcomers without discrimination, as we know Javanese community is well-known for their friendliness to everyone.

\section{REFERENCES}

Angelika, V. 2013. Penyesuaian Mahasiswa Papua di Yogyakarta. Yogyakarta : Tesis UGM

Herimanto, Winarno. 2010. Ilmu Sosial dan Budaya Dasar. Jakarta: Bumi Aksara.

Mardalis. 1999. Metode Penelitian Suatu Pendekatan Proposal. Jakarta : Bumi Aksara

Nazir, M. 1988. Metode Penelitian. Jakarta : Ghalia Indonesia.

Nawawi. H. 1991. Metode Penelitian Bidang Sosial. Yogyakarta : Gajah Mada University Press

Poloma, M.M. 2010. Sosiologi Kontemporer. Jakarta : PT Raja Grafindo Persada

Ritzer, G \& Douglas J.G. 2012. Teori Sosiologi. Bantul : Kreasi Wacana

Skinner, B. F. 1938. The Behavior Of Organisms. Newyork

Yusma, E. 2016. Stereotipe dan Diskriminasi Terhadap Wong Timur: Respon Terhadap Mahasiswa Pendatang di Yogyakarta. Yogyakarta : Tesis UGM

\section{Other :}

CNNindonesia.com, downloaded on May 5th 2018 at 06.09 P.M 